\title{
NOTE
}

\section{Evidence for the direct settlement of Mytilus edulis larvae on adult mussel beds}

\author{
D. McGrath, P. A. King, E. M. Gosling \\ Department of Life Sciences, Regional Technical College, Galway, Ireland
}

ABSTRACT: Investigations on intertidal mussels Mytilus edulis $L$. on an exposed rocky shore in the west of Ireland during 1983 to 1986 revealed a settlement pattern which differs from that reported elsewhere, particularly in Britain. Analysis of the population structure showed the frequent presence of cohorts of individuals $<500 \mu \mathrm{m}$ shell length. These cohorts appeared in the population at times and with a size range which indicates direct settlement from the plankton on the adult beds. $M$. edulis larvae may settle directly on adult beds without the initial primary phase on filamentous substrates postulated by the primary/secondary settlement model.

The larvae of Mytilus edulis become competent to settle at a shell length of ca $260 \mu \mathrm{m}$ but can delay metamorphosis and grow in the plankton until they are ca $350 \mu \mathrm{m}$ (Sprung 1984, Bayne 1965). The association between recently settled $M$. edulis and filamentous substrates such as algae and hydroids has long been recognized (reviewed by Seed 1976). Bayne (1964) first demonstrated the existence of the phenomenon of primary and secondary settlement in $M$. edulis in the Menai Straits (N Wales, UK). $M$. edulis larvae initially settled from the plankton on filamentous algae. Recruitment to the adult beds followed a period of growth and involved a second pelagic phase (Bayne 1964). This second pelagic phase has been termed bysso-pelagic migration or byssus drifting and is facilitated by the production of a long thread (Lane et al. 1985).

In Bayne's (1964) study in the Menai Straits, mussels $<750 \mu \mathrm{m}$ did not occur among the adult beds and the main recruitment occurred at a size range of 1.0 to 1.5 $\mathrm{mm}$. Seed (1969), working on an exposed rocky shore in Yorkshire (NE England), supported the observations of Bayne (1964) and reported recruitment to the adult beds when the majority of the mussels were between 1.0 and $2.0 \mathrm{~mm}$ shell length. The work of Dare (1976) in Morecambe Bay (NW England) also supported the primary/secondary model. Here the smallest individu- als among the adult beds were normally 550 to $700 \mu \mathrm{m}$ shell length and none less than $480 \mu \mathrm{m}$ were seen. Dare (1976) and Dare et al. (1983) characterized mussels of 230 to $400 \mu \mathrm{m}$ shell length as primary settlers and those $>500 \mu \mathrm{m}$ as secondary settlers.

A number of workers have expressed doubts about the applicability of the primary/secondary settlement model to their areas. Bohle (1971), working in a Norwegian fjord, cited the absence of mussels $>400 \mu \mathrm{m}$ from plankton samples as evidence for the absence of a secondary pelagic phase and Kautsky (1982) found no evidence for this phase in his Baltic mussel populations. However, neither author provides data on the population structure of $<1 \mathrm{~mm}$ shell length mussels on adult beds. Cross \& Southgate (1983) recorded a summer mussel recruitment in Bantry Bay, SW Ireland as probably primary settlement but gave no data to support this view.

In laboratory studies on Mytilus edulis from the Pacific coast of North America, Petersen (1984) has shown that larvae will settle on adult conspecifics but exhibit a preference for filamentous algae. Fell \& Balsamo (1985), working in Long Island Sound, USA record primary settlement of $M$. edulis on clean Mercenaria mercenaria cultch. More recently, Eyster \& Pechenik (1987) have shown that $M$. edulis larvae will settle on adult byssal threads in the laboratory and note that their results suggest that some mussel larvae may recruit directly to the adult habitat in the field.

Direct settlement of larvae on adult beds has been previously reported in Mytilus, for $M$. californianus (Petersen 1984).

The present investigation documents the population dynamics of newly settled Mytilus edulis on an exposed rocky shore in Galway Bay, west coast of Ireland, and demonstrates that mussel larvae settle directly on adult beds without an initial primary settlement phase on filamentous algae. This contrasts with 
earlier findings that $M$. edulis displays complex recruitment behaviour involving primary and secondary phases.

Materials and Methods. Standard areas of 25 or $9 \mathrm{~cm}^{2}$ were scraped from the mussel beds on the lower shore on an exposed rocky shore at Ballynahown in Galway Bay (Irish National Grid Reference L9920). Samples were collected once a month from December 1983 to November 1984 and at varying intervals after that until September 1986. Only mussels < $1 \mathrm{~mm}$ were measured, to an accuracy of $50 \mu \mathrm{m}$. Length frequencies for the $<1 \mathrm{~mm}$ mussels were estimated from a subsample of the $25 \mathrm{~cm}^{2}$ samples. For $9 \mathrm{~cm}^{2}$ samples the whole sample was used. Mussel density and estimates of the percentage contributions of the $<1 \mathrm{~mm}$ and $<400 \mu \mathrm{m}$ individuals (Table 1) were calculated only for samples where all the mussels were counted.

Table 1 Mytilus edulis. Density of $<1 \mathrm{~mm}$ mussels and percentage contribution of $<1 \mathrm{~mm}$ and $<400 \mu \mathrm{m}$ mussels to the population structure of lower shore mussels at Ballynahown

\begin{tabular}{|c|c|c|c|}
\hline \multirow[t]{2}{*}{ Dates } & \multicolumn{2}{|c|}{$\%$ Contribution: } & \multirow{2}{*}{$\begin{array}{l}\text { Density } \\
\left(\mathrm{cm}^{-2}\right)\end{array}$} \\
\hline & $<1 \mathrm{~mm}$ & $<400 \mu \mathrm{m}$ & \\
\hline 20 Nov 1983 & 77.6 & 10 & not known \\
\hline 21 Dec 1983 & 85.4 & 38 & 83.9 \\
\hline 2 May 1984 & 23.4 & 1 & 5.8 \\
\hline 15 May 1984 & 38.4 & 12 & 13.1 \\
\hline 10 Oct 1984 & 46.4 & 24 & 25.8 \\
\hline 17 May 1985 & 39.3 & 3 & 20.3 \\
\hline 5 Jun 1985 & 43.6 & 16 & 30.7 \\
\hline $18 \mathrm{Jul} \quad 1985$ & 30.4 & 3 & 12.6 \\
\hline 20 Aug 1985 & 33 & 3 & 16.7 \\
\hline $18 \mathrm{Sep} 1985$ & 38.4 & 4 & 15.6 \\
\hline $10 \mathrm{Sep} 1986$ & 56.8 & 18 & 42 \\
\hline$\overline{\mathrm{X}}$ & 47 & 12 & 27 \\
\hline
\end{tabular}

Results. Mussels < $1 \mathrm{~mm}$ shell length were abundant in the adult beds at Ballynahown throughout the study period and comprised on average $47 \%$ of the population with a range of 23 to $85 \%$ (Table 1). Density of these $<1 \mathrm{~mm}$ individuals ranged from 5.8 to $83.9 \mathrm{~cm}^{-2}$, with a mean of $27 \mathrm{~cm}^{-2}$. The length frequency data (Fig. 1) show that individuals $<500 \mu \mathrm{m}$ shell length dominated the $<1 \mathrm{~mm}$ population from December 1983 until April 1984 with the principal mode at $425 \mu \mathrm{m}$.

By the beginning of May 1984, mussels $>500 \mu \mathrm{m}$ became dominant. At the end of May, a new peak of $<500 \mu \mathrm{m}$ individuals with the mode at $375 \mu \mathrm{m}$ appeared. This mode shifted to the right in subsequent months. Throughout May to September the $>500 \mu \mathrm{m}$ fraction remained relatively abundant. In October 1984, a new prominent cohort with a modal length of $375 \mu \mathrm{m}$ appeared along with a relative decline in importance of the $>500$ um fraction. A similar popula-

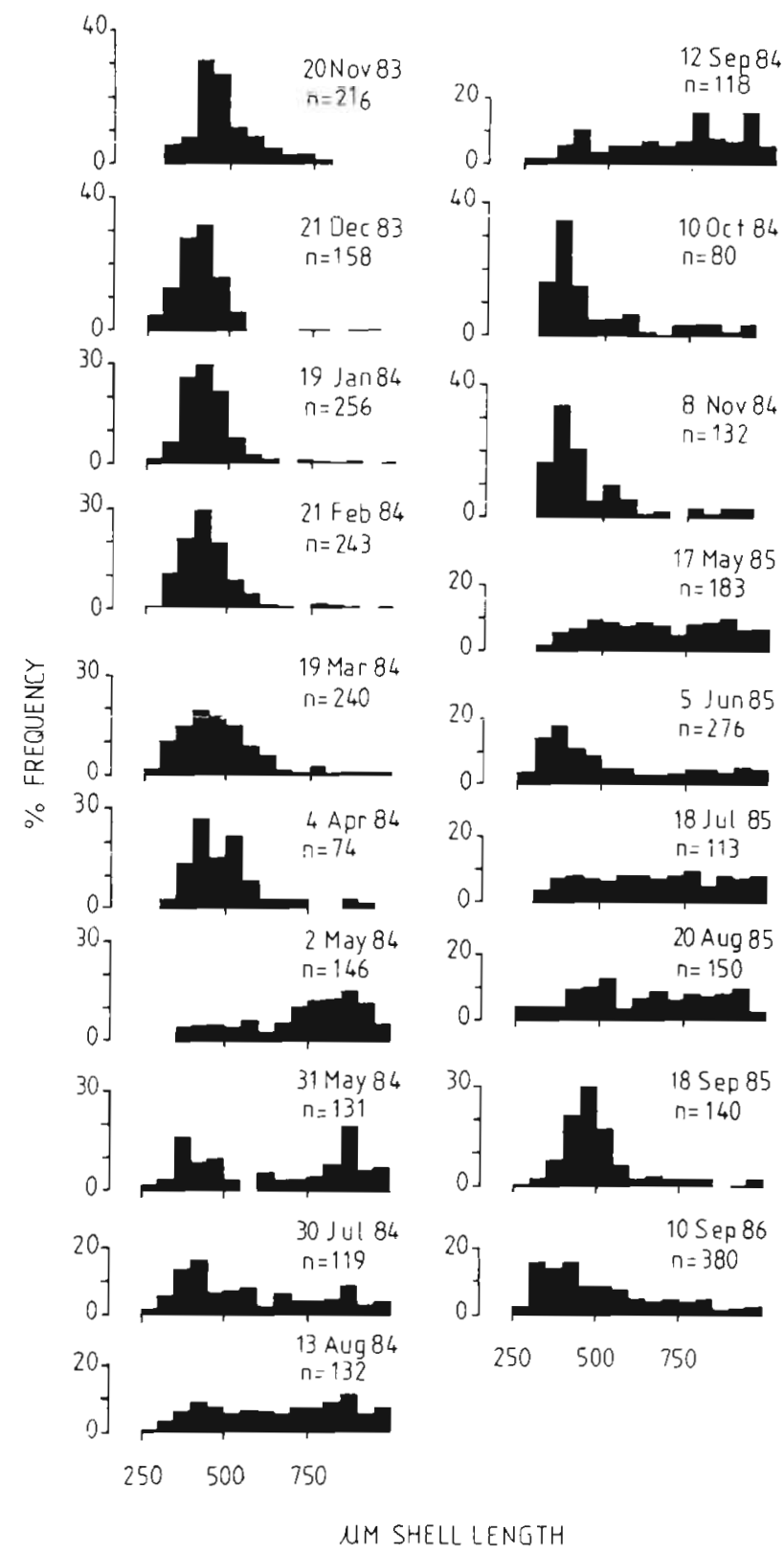

Fig. 1. Mytilus edulis. Percentage length frequency distribution for the $<1 \mathrm{~mm}$ shell length mussels from the adult beds at Ballynahown, November 1983 to September 1986

tion structure was evident for November 1984. The population for May 1985 was similar to that of early May 1984. In early June 1985, a new cohort appeared with a modal size of ca $375 \mu \mathrm{m}$. As in the summer of 1984 this mode shifted to the right in subsequent months and the $>500 \mu \mathrm{m}$ mussels remained relatively abundant. In September $1985<500$ um mussels again predominated with a modal length of $475 \mu \mathrm{m}$. The only sample thus far analysed for 1986 (September) displays a population structure dominated by $<500 \mu \mathrm{m}$ individuals with a somewhat bimodal frequency distribution and 
modes at 325 and $425 \mu \mathrm{m}$. Individuals $<400 \mu \mathrm{m}$ formed on average $12 \%$ of the total mussel population, ranging from 1 to $38 \%$ (Table 1). The maximum density estimated for these $<400 \mu \mathrm{m}$ mussels was $37 \mathrm{~cm}^{-2}$.

Discussion. During the $4 \mathrm{yr}$ of the investigation at Ballynahown, mussels $<400 \mu \mathrm{m}$ shell length frequently made a significant contribution to the population structure of the adult beds. This contrasts sharply with results published elsewhere in Europe, particularly in Britain. The population structure data (Fig. 1) from Ballynahown demonstrates 2 recruitment periods to the adult beds, an autumn recruitment in September/October and a summer recruitment in May/ June. The modal size of these recruits lies within the range 300 to $400 \mu \mathrm{m}$ with the single exception of September 1985 when the mode was at $475 \mu \mathrm{m}$. Following Dare (1976) and Dare et al. (1983), the appearance of these modes indicates primary settlement i.e. direct settlement from the plankton without an initial growth phase on filamentous substrates. At settlement times these $<400 \mu \mathrm{m}$ mussels made up 10 to $38 \%$ of the population, again with the single exception of September 1985 (Table 1). There is an indication in the data for August 1985 (Fig. 1) that settlement may have started then. If so, then the larger size seen in September may be due to the growth of the settling cohort prior to sampling.

The settlement periods observed in the adults beds, May/June and August (?) to October follow the major spawning periods of the mussels at Ballynahown given that Mytilus edulis has a planktonic life of 4 to $10 \mathrm{wk}$ (Seed 1976) and are contemporaneous with direct settlement there on filamentous algae (authors'obs.).

Why the pattern at Ballynahown differs from that observed at sites in Britain is not known. There are genetic differences between the mussel populations at Ballynahown and those in the Irish Sea where Bayne (1964) and Dare (1976) worked. Irish Sea mussels are Mytilus edulis whereas the mussels on exposed Atlantic sites such as Ballynahown are a mixture of $M$. edulis and a form not considered to merit separate species status, M. galloprovincialis (Gosling \& Wilkins 1981, Gosling 1984). Thus, genotypic differences might account for the differences observed. However, Seed's (1969) site in NE England lies within an area where M. galloprovincialis is known to occur (Skibinski \& Beardmore 1979), making it appear unlikely that genetic differences alone are responsible for the contrasting settlement patterns.

Decisions as to whether observed differences in settlement patterns are due to preferential settlement or post-settlement differential mortality may be confounded by the fact that settlement per se is not observed but inferred from observations made some time later (Keough \& Downes 1982). The difference between the pattern recorded at Ballynahown and that reported for British waters could, theoretically, be due to differential mortality of recently settled post-larvae on adult beds. However, for this to be true, mortality would have had to be so severe on the British sites examined as to preclude the collection of any recently settled individuals. In this case, the only successful recruits would be immigrating cohorts which had grown to secondary settlement size in other habitats. Alternatively, Mytilus edulis larvae may have broader settlement preferences at Ballynahown in that settlement occurs not only on filamentous algae, as at the British sites, but also on adult beds.

It is not known whether the pattern at Ballynahown is the norm for other Irish exposed shore populations. Furthermore, the data presented in this account do not preclude the possibility that cohorts also recruit to the adult beds at Ballynahown at secondary settlement size following initial settlement on other substrates such as filamentous algae.

The existence of varying modes of settlement in Mytilus edulis may be yet another example of the plasticity seen in the biology of this species. Whether the mode seen on any particular shore is genetically based or a response to varying environmental factors has yet to be elucidated.

Acknowledgements, We thank Michael Gilooly, Frank O'Donoghue, Frank Flanagan and Michael Grogan for their assistance and Drs Ray Seed and Maria Byrne for helpful comments on the manuscript. The project was funded by the Irish National Board for Science and Technology, grant 96/84.

\section{LITERATURE CITED}

Bayne, B. L. (1964). Primary and secondary settlement in Mytilus edulis L. J. Anim. Ecol 33: 513-523

Bayne, B. 1. (1965). Growth and the delay of metamorphosis of the larvae of Mytilus edulis (L.). Ophelia 2: 1-47

Bohle, B. (1971). Settlement of mussel larvae Mytilus edulis on suspended collectors in Norwegian waters. In: Crisp, D. J. (ed.) Fourth European Marine Biological Symposium. Cambridge University Press, London, p. 63-69

Cross, T. F., Southgate, T. (1983). An approach to ecological monitoring in the rocky intertidal: a survey of Bantry Bay and Dunmanus Bay, Ireland. Mar. environ. Res. 8: 149-163

Dare, P. J. (1976). Settlement, growth, and production of the mussel, Mytilus edulis L., in Morecambe Bay, England, Fishery Invest., Lond. II 28: 1-25

Dare, P. J., Edwards, D. B., Davies, G. (1983). Experimental collection and handling of spat mussels (Mytilus edulis L.) on ropes for intertidal cultivation. MAFF (Lowestoft) Fish. Res. Tech. Rep. No. 74: 1-23

Eyster, L. S., Pechenik, J. A. (1987). Attachment of Mytilus edulis L. larvae on algal and byssal filaments is enhanced by water agitation. J. exp. mar. Biol. Ecol. 114: 99-110

Fell, P. E., Balsamo, A. M. (1985). Recruitment of Mytilus edulis L. in the Thames Estuary, with evidence for differences in the time of maximal settling along the Connecticut shore. Estuaries 8: 68-75 
Gosling, E. M. (1984). The systematic status of Mytilus galloprovincialis in western Europe: a review. Malacologia 25: $551-568$

Gosling, E. M. Wilkins, N. P. (1981). Ecological genetics of the mussels Mytilus edulis and $M$. galloprovincialis on Irish coasts. Mar. Ecol. Prog. Ser. 4: 221-227

Kautsky, N. (1982). Quantitative studies on gonad cycle, fecundity, reproductive output and recruitment in a Baltic Mytilus edulis population. Mar. Biol. 68: 143-160

Keough, M. J., Downes, B. J. (1982). Recruitment of marine invertebrates: the role of active larval choices and early mortality. Oecologia 54: 348-352

Lane, D. J. W., Beaumont, A. R., Hunter, J. R. (1985). Byssus drifting and the drifting threads of the young post-larval mussel Mytilus edulis. Mar Biol. 84: 301-308
Petersen, J. H. (1984). Larval settlement behavior in competing species: Mytilus californianus Conrad and $M$. edulis L J. exp. mar. Biol. Ecol. 82: 147-159

Seed, R. (1969). The ecology of Mytilus edulis L. (Lamellibranchiata) on exposed rocky shores. 1 Breeding and settlement. Oecologia 3: 277-316

Seed, R. (1976). Ecology. In: Bayne, B. L. (ed.) Marine mussels their ecology and physiology. IBP 10, Cambridge Univ Press, London, p. 13-65

Skibinski, D. O. F., Beardmore, J. A. (1979). A genetic study of intergradation between Mytilus edulis and Mytilus galloprovincialis. Experientia 35: 1442-1444

Sprung, M. (1984). Physiological energetics of mussel larvae (Mytilus edulis). I. Shell growth and biomass. Mar. Ecol. Prog. Ser. 17: 283-293

This note was submitted to the editor; it was accepted for printing on May 4, 1988 